\title{
Działalność Studenckiego Koła Naukowego Architektury Informacii w roku akademickim 2016/2017
}

W marcu 2017 r. z inicjatywy studentów kierunku architektura informacji, prowadzonego przez Instytut Informacji Naukowej i Bibliologii UMK [dalej: IINiB UMK], powstało Studenckie Koło Naukowe Architektury Informacji [dalej: SKN AI]. Członkowie koła pragną skoncentrować się na działalności online. Przyjęta formuła ma pozwolić na szybką i efektywną realizację inicjatyw, testowanie i poznawanie nowoczesnych aplikacji, a także na skupienie się na istocie dziedziny, wokół której roztacza się działalność koła - czyli architekturze informacji. SKN AI ma na celu nie tylko rozwijanie zainteresowań naukowych, ale również monitorowanie i dopasowanie się do trendów panujących na rynku pracy.

Na czele zarządu stanęła pomysłodawczyni koła - Julia Hladiy, jej zastępcą został Daniel Biesiada, natomiast funkcję skarbnika i sekretarza objęła Anna Roszak. Opiekę merytoryczną nad SKN AI, które w chwili jego uruchamiania zrzeszało dziewięcioro członków, zgodziła się objąć dr Natalia Pamuła-Cieślak.

Od marca do czerwca 2017 r., czyli podczas czterech pierwszych miesięcy działalności SKN AI, członkowie koła podjęli się organizacji oraz uczestniczyli w szeregu inicjatyw. Były to:

1. Otwarcie kanałów social media SKN AI w serwisach Facebook (https://www.facebook.com/sknaiumk), YouTube (SKNAI UMK), Instagram (@sknai_umk) oraz Twitter (@sknai_umk).

2. Uczestnictwo w Pierwszym Dniu Wiosny na Wydziale Nauk Historycznych UMK - przeprowadzenie konkursu o Open Access oraz prezentacja działalności koła na stoisku.

3. Pomoc przy konferencji „Wizualizacja informacji w Humanistyce” - realizacja fotoreportażu, wideorelacji, obróbki zdjęć, relacji na żywo w social mediach IINiB UMK. 
4. Rewitalizacja półki bookcrossingowej w budynku Wydziału Nauk Historycznych, czyli Collegium Humanisticum - opracowanie i przywieszenie nowego napisu „Bookcrossing”, przygotowanie tablicy informacyjnej na temat charakteru akcji oraz zasilenie półki kilkudziesięcioma nowymi pozycjami książkowymi i prasowymi.

5. Stworzenie GiveBoxa - punktu, w którym można oddawać niepotrzebne rzeczy w dobrym stanie oraz zabierać to, czego się potrzebuje. Póki co GiveBox przybrał formę pudełka ustawionego na regale bookcrossingowym.

6. Udział w drzwiach otwartych w IX LO w Toruniu im. Kazimierza Jagiellończyka - prowadzenie działań promocyjnych na rzecz IINiB UMK.

7. Wsparcie i pomoc techniczna podczas ogólnoeuropejskiej kampanii: Tydzień z Internetem” pod hasłem „e-Pasjonaci” na warsztatach dla seniorów i studentów oraz spotkania z blogerami organizowanego przez dr Magdalenę Cyrklaff.

8. Udział członków koła w „II Forum Praktykujących Pisanie” (Bydgoszcz, 27 marca 2017 r.).

9. Udział członków koła w konferencji „Jungle Web” (Łódź, 6-7 kwietna 2017 r.).

10. Udział członków koła w konferencji „Firma przyszłości” (Toruń, 6 czerwca 2017 r.).

Najważniejszym przedsięwzięciem planowanym na kolejny rok akademicki jest uruchomienie strony internetowej wraz z blogiem, która ma być od podstaw (od szablonu po treść) stworzona i rozwijana przez członków koła. Planowane jest także kontynuowanie i rozwijanie działalności koła w mediach społecznościowych, jak również sprawowanie pieczy nad półką bookcrossingową i GiveBoxem. Oprócz tego członkowie SKN AI mają zamiar w dalszym ciągu brać czynny udział w konferencjach, warsztatach i targach pracy.

Julia Hladiy

Przewodnicząca Studenckiego Koła Naukowego Architektury Informacji 